


\title{
THE BATTLE OF PLEASANT HILL, LOUISIANA.
}

\author{
Recollections of a Private Soldier.
}

BY A. J. BARKLEY.

By a curious coincidence the Battle of Pleasant Hill, while not exactly ignored, has remained an affair of comparative slight mention, both in official reports and in the histories of the civil war. True, the bloody battle of Mansfield took place the day previous, but in this the forces were largely from the east. Only a portion of two Iowa regiments took part in that engagement. The death of Col. Lewis Benedict, a prominent New Yorker, seems to have eclipsed most of the other losses, and some of the western troops which suffered severely, have received but scant justice from the Muse of History. It is not with the idea of righting this wrong that I have prepared this article, but to present the readers of THE AnNals with a private soldier's recollections of one of the bloodiest and most stubbornly contested battles of the war. For the nature and results of the "Red River Expedition" the reader is respectfully referred to the official reports and to Badeau's Military History of General Grant.

Premising, however, that he will find the records of our Iowa soldiers but meagerly set forth, I hope I shall at least be able to convince those who do me the honor of reading this narrative, that the Iowa soldiers upheld the honor and good name of their State on that day.

I was a member of Co. "D," 32d Iowa Infantry, enlisted in Boone county. Our regiment spent the night of April 8th, 1864, in the woods just east of Pleasant Hill, Louisiana. It was dark when we went into camp in the cemetery at the top of the hill. The little mounds were fenced in with rail pens and covered with poles to prevent the intrusion of live stock. Everything was wet, and we were obliged to split some of the rails into kindling to start a fire 
alongside of a big log, where we could make our coffee. Other companies did likewise, and the camp soon took on a cheerful appearance. The omnipresent "hard tack" and a little hot coffee constituted our suppers. We had no tents, but wrapped in our army blankets lay down upon the ground, among the wet bushes, under a cloudy sky, to get what rest we could.

Before going to sleep I was detailed for duty, and not relieved until morning. Soon after daylight we were preparing our breakfasts. Our mode of cooking was simple even for soldiers. We used a small fruit can with a wire bail; each soldier had his own; on the march it answered for a tin cup, and in camp it served for a coffee pot. We held the cans over the fire with our ramrods until our coffee boiled, and on the end of a sharp stick grasped in the other hand, we broiled a bit of fat salt pork, which was quite a luxury at that particular time.

Stragglers from Banks' army had begun to come in before midnight, at first in small squads, and by the time we had our breakfast, they came by scores and by hundreds, in disorder and confusion. Excitement began to run high, for no fight had been anticipated until near Shreveport. Everybody was discussing the rumors brought in and seriously considering the probabilities of a battle during the day.

Some of the stragglers referred to had been wounded in the desperate engagement near Mansfield the day before. They said Dick Taylor's army had whipped the 13th corps, one detachment at a time, and had driven it back to the "saw mill," and after heavy fighting with the 19th corps, Banks had been severely beaten, losing heavily in killed, wounded and prisoners. The rebels had captured hundreds of mules, horses and wagons, together with provisions and other supplies, besides getting about twenty-five field pieces. Banks' wagon train was well to the front, blockading the road for a long distance. His men were too far apart to successfully resist such a fierce attack, and his army got away in bad shape.

Our brigade was commanded by Col. W. T. Shaw. Capt. 
'Charles T. Granger, now a judge of the Supreme Court, was Acting Assistant Adjt.-General on Shaw's staff. We were soon ordered to move forward. Our knapsacks were left behind to lighten our burdens, and going but a short distance we turned squarely to the left and took our position in the edge of the woods, facing an open field between us and the rebels. A heavy skirmish line was at once thrown forward "to feel the enemy." This line, of which I was a part, was located in a swale midway across the field. The enemy's cavalry was partially concealed by the woods some distance in front of us; their infantry lay close behind the eavalry. Occasional shots were exchanged during the day. No preparation in the way of trenches or temporary breastworks had been made by our main line to prevent the awful destruction of life and limb that followed that afternoon.

It was long after the noon hour when I shared the contents of my haversack with our Major, G. A. Eberhart, who lay near me, watching the movements of the enemy.

About 4:00 p. m. the cavalry made a dash from the woods, intending to eut us off, but we fell back on a dead run. The bullets cut the dirt about our feet at every step. We escaped with but slight loss, falling in with the main line. A heavy fire was opened upon one of our batteries, which was soon disabled and sent to the rear. Their cavalry then made a desperate charge on our brigade; they came upon us like a hurricane; clouds of dust filled the air. The rumbling sound of horses' feet, thundering across the field on a keen gallop, the clanking of a thousand sabers, the rebel yell of that advancing host, armed with trusty carbines and navy revolvers, was enough to strike terror to the hearts of the bravest. They were determined to break our line. We looked into the faces of these desperate men as they were elosing the narrow gap between us. Their excited horses with open mouths and distended nostrils, came like a herd of wild buffaloes stampeded by a prairie fire. Escape was impossible. To remain seemed instant death. Suddenly a blaze of musketry several hundred feet long lit up the edge of the woods where our line lay flat on the ground for shelter. The terrible vol- 
ley staggered them. Nearly every saddle was emptied. In their maddened fright riderless horses felli upon or trampled. the dead and wounded under their feet. The tattered remnant would have beaten a hasty retreat on foot, but were literally cut to pieces by another volley, which made their destruction complete.

The infantry, in double column, then made a determined charge on our line. They came on a "double quick," with. their muskets at a "right shoulder shift," with the coolness of a brigade on inspection, apparently not knowing exactly where our brigade lay concealed. Their advance was mown down like grass, until, panic stricken, the rest of the column turned back and were almost swept out of existence by a murderous cross fire. The enemy then stretched a heavy line across the entire field. They crowded hard upon us, but were met with such a storm of bullets that they fell to the ground and crawled upon us like army worms. The cannonading was fierce upon both sides; their shot and shell crashed through the trees; great limbs were torn from their holdings and dropped among us; the bullets flew thick and fast and we could see but a little distance, our vision being almost wholly obseured by the dense clouds of smoke which hung over the field. Their ranks were so fearfully thinned that their dead and wounded covered the ground like unshocked sheaves of grain in harvest time. They soon became demoralized; order could not be restored, and, disheartened and discouraged, they fell back sullenly under a heavy fire.

While resting my elbow on the ground, taking close aim at a man, who was crawling in advance of the others, under shelter of a wash-out, my gun dropped suddenly from my grasp; my right shoulder had been pierced by a minie ball. It shattered the bone from the shoulder downward. My first. thought was to crawl back to a place of safety, but the firing in the rear indicated that we had been surrounded. Seeing that an attempt to get away might result in my capture, I decided to take my chances with the boys and remain where $\mathbf{I}$ was, reatizing that darkness would soon close the bloody scenes of the day. 
Jed. Starr was busy on my right. He loaded his gun: while lying on his back; then turning on his side and rising upon his elbow he would fire. Observing shortly after that he was lying awkwardly on his side, with his legs drawn up and fresh blood oozing from his blouse, I knew what had occurred. Turning my face to the left I saw Corporal Pettibone lying motionless, with his eyes half closed and his mouth slightly open. I knew at once that he had been killed.

About this time the rest of our brigade dropped back a hundred yards or more. The enemy had been sorely punished. Heavy clouds of smoke hung over the field. Darkness was upon us. Our regiment was the last to leave the scene of action. The enemy's line being longer than ours had swung around and got in behind us. Being in the woods they were not aware that their army in front of us was falling back. Our gallant Col. Scott ordered us to cut our way out as best we could. After a sharp fight we succeeded in breaking through their line. In the hand to hand encounter which took place in the darkness, we took about fifty of their men prisoners and they captured about the same number of ours. The question as to which man should be the prisoner depended entirely upon who got "the drop" on the other. My arm was so benumbed from the shock that I was suffering but little pain. The battle, as well as the great nervous strain upon us, was over. My thoughts began to run back to the dead comrades on the field. My heart was heavy, as I wondered who and how many would be able to answer to roll-call that night. I could almost hear the widow's moan and the orphan's wail, as I thought of the stricken families at home.

We had been confronted by 17,000 men, flushed with the victory of the day before. Consternation had seized the enemy who was already trying to get a safe distance from us, expecting to be followed on the morrow. Both armies had lost heavily. Every inch of ground had been stubbornly contested by both sides, and it was difficult to tell who had suffered most. Lieut-Col. Edward H. Mix and Adjutant Charles H. Huntley had been killed. Captains Miller, Pee- 
bles and Ackerman; Lieutenants Wright, Howard, Bannon, Devine and other officers had been wounded.

On leaving the ground occupied by our company, I glanced hastily about me. There lay our dead and wounded-John E. R. Wright, Moses Capps, M. Pettibone, Nick Harter, W. B. Lawton, Peter Batten, Jed. Starr, Thomas B. Thompson, and William M. Peoples, had been killed. Several of our company were slightly wounded, and Samuel C. Blunk, Frank Spurrier, John Weston, John H. Merrick, Tom Spickelmire, Albert Davis, Ben Hickman and the writer, had been severely wounded. Several of these men soon died of their wounds. Sargeants D. S. Jewett and J. G. Miller, Corporal Dan W. Robbins, G. L. Joyce, William Manchester, Gust. Linn and Tice Buffington of our company, with about forty others from our regiment, were taken by the enemy to Tyler, Texas, where Miller died and Jewett escaped from prison and finally reached the Union lines in safety.

I saw John McMiller of Co. "A," who was afterward sheriff of Hamilton county, Iowa. He had been struck in the forehead with a ball which passed out at the temple, tearing away an eye. In a few minutes officers were calling their men into line to get a list of the killed, wounded and missing. My wound was bleeding profusely, and I determined to hunt up a surgeon as soon as possible. In company with James Atkinson I walked through the woods, where, safely in the rear, our surgeons were bestowing such eare as was possible to skilled and willing hands by the flickering light of fires and torches. I passed several tents where this was going on, until I came to a comfortable looking house well lighted up and appearing somewhat more inviting. A good old Quaker lady stood inside the door. By her permission I walked in and laid down on the floor. Several badly wounded men were already there. It soon came my turn. Surgeon Sanger, Medical Director of the 19th corps, came up and said,- "What is the matter with you, my boy?" I made no audible reply, but pointed with my left forefinger to my right shoulder. Quick as thought he knelt on one knee, found the bullet hole in my blouse, and thrust his finger deep 
into the wound, twisting it about to explore the extent of the injury. "Get up on this table," said he, "and I will attend to you right off." Slowly pulling myself together, I arose and laid down on the short table, my legs from the knee down dangling in the air. He quickly eut away my garments, and after a hurried examination suggested chloroforming me and taking my arm off at the shoulder. I objected to amputation, and for that reason would not take chloroform. He then decided to unjoint my right arm at the shoulder and remove the bone. He said the arm would fill a coat sleeve if I lived, and in any event the experiment would enable him to operate with some degree of success on others. He sawed off the bone in the right arm below the fracture, took it out, sewed up the wound, laid me on the floor in the hall, and went to work on others. A piece of "dog tent" was thrown over me to cover my nakedness. About daylight the corn meal was scraped up from the ground where the mules had been fed and made into mush, which constituted the breakfast of these wounded boys.

Smith's corps had saved our army. Shaw's brigade had sustained the heaviest loss. Our regiment had lost 50 per cent of its men engaged in that day's battle.

Gen. Smith, next morning, desired to pursue the enemy, who by this time was in full retreat, but Gen. Banks denied him even the privilege of remaining long enough to bury his dead, and began his disgraceful retreat at daybreak. An hour or two after sunrise a detail of Confederates came back under flag of truce to bury their dead. Taking in the situation, and finding the field unoccupied, save by the dead and wounded, word was sent back to their retreating army, now nearly a dozen miles away, and in a few hours their cavalry was in hot pursuit of Gen. Banks, who by this time had lost the confidence and respect of his army and demonstrated his incapacity as a soldier.

A rebel officer came into the house where a dozen of us lay and generously offered us a swallow of rum from his canteen, saying, "You may consider yourselves our prisoners." At the end of four days Solon F. Benson and I were the only 
survivors in the house. Benson had lost his right arm near the shoulder and looked like a ghost. We were then taken on a dray about a third of a mile where several hundred prisoners were guarded. Being helpless on account of starwation and loss of blood, room was soon provided for me by the removal of a dead soldier from his place.

Two large unfurnished brick buildings, two stories high, accommodated persons whose wounds were thought to be fatal. We were laid side by side on the bare floor, our heads to the wall, in a row extending around the entire room. This left room for another tier which occupied the center.

The prisoners died off rapidly and there was soon plenty of room. This was utilized by surgeons in cutting off arms and legs which were sometimes thrown out of the windows and carried off by the hogs.

Prison life here was not unlike that at Libby, Andersonville, and other rebel prisons, about which so much has been said and written. Green flies swarmed everywhere. Buzzards blackened the sky after feasting on the miserable remains of hundreds of dead horses lying on the field. The stench was most intolerable. There was a fine spring of water about sixty rods from our brick prison. Near the spring stood a large frame house filled with wounded prisoners. Our road to the spring led through the woods. All the water used for drinking purposes, dressing wounds, cooking, etc., had to be carried in pails. This was done by wounded men. To avoid the flies and hot weather they made the trips between sunset and sunrise. Water was thus hard to get and very scarce, not even enough could be had to wash our faces. The boys in the frame house near the spring fared better, so far as the water supply was concerned. The men whose wounds were slight were marched off to Tyler, Texas, under guard.

For some time we were furnished two rations a day of eorn meal gruel. Then came a change; we were furnished with beef twice a week, and the corn meal, mixed with water, was put into an oven and made into "corn pone." The oven had legs so that a fire could be built under and about it; 
coals were piled on the lid and it quickly gave the "pone" a nice brown color before it was half cooked; after cooling it was cut into small slices and each man got one. The beef was boiled in a large iron kettle, cut into small bits and laid in an improvised shed made of brush. This never reached us until it was "fly-blown," but it sufficed to keep life in some of us until we were little more than skeletons. Lint and bandages had been sent us under flag of truce. One of the boys escaped and was followed by bloodhounds, which he threw off the scent by rubbing his feet and the soles of his shoes with onions, taken during the night for that purpose from a garden near the spring.

At the end of two months some of us were transferred in wagons to Mansfield, where we found a number of prisoners who had been wounded and eaptured in the first day's fight. About two weeks after this all whose wounds were of such a nature as to render them forever unfit for service were sent by boat to the mouth of the Red River and paroled.

As we neared Alexandria I saw Bob Mack of Co. "A," walking barefooted and bareheaded, followed by two rebel soldiers. He had escaped at Mansfield about two weeks previously. Bob was allowed to join us on the boat. The story of his escape and final capture after having been torn by the hounds was most thrilling, and made him seem like one of the heroes described by the novelist. We were soon at the mouth of Red River where several of our boats lay at anchor. Not one of us had received a letter or seen a paper since our capture. We had not heard that a call had been made for "hundred-day" men, who had already been put in the field.

The sight of the stars and stripes and well fed men in blue filled us with gladness; some began to sing, some wept for joy, while others shouted and thanked God for liberty.

Boone, Iowa, December, 1896. 
Copyright of Annals of Iowa is the property of State of Iowa, by \& through the State Historical Society of Iowa and its content may not be copied or emailed to multiple sites or posted to a listserv without the copyright holder's express written permission. However, users may print, download, or email articles for individual use. 